\title{
Ultrastructural Studies of the Cells Forming Amyloid Fibers in Classical Plaques
}

\author{
H.M. Wisniewski, J. Wegiel, K.C. Wang, M. Kujawa and B. Lach
}

\begin{abstract}
Three-dimensional reconstruction and ultrastructural studies of classical plaques from the cortex of patients with Alzheimer's disease showed that microglial cells of the plaques are the amyloid-forming cells. The amyloid star of the single plaque represents the product of five or six microglial cells covering about $80 \%$ of the amyloid star surface. The amyloid fibers appear to be formed within altered cisterns of the endoplasmic reticulum. Distended cisterns form channels filled with amyloid fibers. Numerous vesicles derived from the Golgi apparatus appear to be attached to or fused with the amyloid-filled channels. Reconstruction of the amyloid star and the microglia cell pole that forms the amyloid star reveals three different zones of distribution of cytoplasmic organelles and amyloid deposits. The peripheral zone comprises channels filled with loosely packed amyloid fibers arranged in a parallel manner. The transient zone consists of a mixture of fusing amyloid channels and products of disintegration of cytoplasmic pockets, dense bodies and fragments of cellular membranes. The core of the amyloid star is composed of condensed, densely packed amyloid fibers that are free of cellular debris. Formation of the three zones supports the idea that the microglia/macrophages are not phagocytes but instead are the cells manufacturing the amyloid fibers.
\end{abstract}

\begin{abstract}
RÉSUMÉ: Études ultrastructurales de cellules formant des fibres amyloïdes dans les plaques classiques La reconstruction en trois dimensions et des études ultrastructurales des plaques classiques provenant du cortex de patients atteints de la maladie d'Alzheimer ont montré que les cellules microgliales des plaques sont probablement les cellules qui forment la substance amyloïde. L'étoile amyloïde d'une seule plaque est le produit de cinq ou six cellules microgliales couvrant à peu près $80 \%$ de la surface de l'étoile amyloïde. Les fibres amyloïdes semblent être formés à l'intérieur de citernes anormales du réticulum endoplasmique. Des citernes distendues forment des canaux remplis de fibres amylö̈des. De nombreuses vésicules formées à partir de l'appareil de Golgi semblent être attachées ou fusionnées aux canaux remplis de substance amyloïde. Une reconstruction de l'étoile amyloïde et du pôle cellulaire microglial qui forme l'étoile amyloïde révèle trois zones différentes de distribution des organelles cytoplasmiques et des dépôts amyloïdes. La zone périphérique comprend des canaux remplis de fibres amyloïdes en amas étalés, disposés de façon parallèle. La zone de transition consiste en un mélange de canaux amyloïdes se fusionnant et de produits de la désintégration de pochettes cytoplasmiques, de corps denses et de fragments de membranes cellulaires. Le coeur de l'étoile amyloïde est composé de fibres amyloïdes condensées, en amas serrés, qui sont exempts de débris cellulaires. La formation des trois zones supporte l'idée que les cellules microgliales/macrophages ne sont pas des phagocytes mais bien des cellules fabriquant des fibres amyloïdes.
\end{abstract}

Can. J. Neurol. Sci. 1989; 16:535-542

Microglial cells were originally recognized as a cell population distinct from other glial cells by Del Rio-Hortega, who used silver impregnation methods for their identification. ${ }^{1}$ Acceptance of microglia as a distinct cell population was hindered by difficulties encountered in identifying them by means of electron microscopy. ${ }^{2-4}$ The combination of silver staining and close correlation with light microscopy subsequently yielded a definitive identification of the microglial cell group. ${ }^{5-8}$

Microglial cells were characterized as small oval cells with a variable number of branching processes and scant cytoplasm which usually contained dense bodies. 5-7,9,10
Four different forms of microglia have been identified: (1) resting or ramified, (2) reactive, (3) amoeboid which is recognized as a transient cell form during development and (4) round cell which is restricted to the early postnatal period. Ramified microglia, which are derived from the amoeboid form and have a lower level of phagocytic activity, are considered to be quiescent precursors of the reactive cell. 11,12

Ultrastructural studies of neuritic (senile) plaques in humans and animals 12,13 have described cells that are associated with deposits of amyloid fibers. These cells have the appearance of reactive microglia and macrophages. Because some have the

From the Department of Pathological Neurobiology, New York State Institute for Basic Research in Developmental Disabilities, Staten Island, N.Y. (HMW and KCW) and the Anatomical Pathology Laboratory Medicine, Ottawa (BL).

JW is a visiting scientist from the Institute for Psychiatry and Neurology, Warsaw and MK is a Fogarty visiting scientist from the Institute of Biostructure Medical School, Laboratory of Electron Microscopy, Warsaw.

Reprint requests to: H.M. Wisniewski, M.D., Ph.D., Institute for Basic Research in Developmental Disabilities, 1050 Forest Hill Road, Staten Island, New York, USA. 10314 
morphological features of macrophages, the question arises whether they function as phagocytes removing the amyloid deposits or engage in production of amyloid. The purpose of this study was to demonstrate, on the basis of serial semithin and ultrathin sections and computer-aided reconstruction of classical plaques, that the microglia/macrophages are the cells in which amyloid fibers are manufactured.

\section{Methods ANd Materials}

Biopsy material from the cortex of a 72-year-old woman with Alzheimer's disease was used for this study. Tissue was fixed in $3 \%$ glutaraldehyde in $0.1 \mathrm{M}$ phosphate buffer, $\mathrm{pH} 7.4$ and postfixed in $1 \%$ osmium tetroxide in Sorensen buffer, $\mathrm{pH}$ 7.4. After dehydration, material was embedded in Epon.

Areas rich in plaques were chosen using sections stained with toluidine blue. Two punctures made in this region in the Epon block served as reference points for three-dimensional reconstruction. Tissue blocks were cut serially in semithin $(0.3 \mu \mathrm{m})$ and ultrathin $(0.06 \mu \mathrm{m})$ sections alternately. Ultrathin sections were stained with uranyl acetate and lead citrate. Three classical plaques were reconstructed from 22, 34 and 48 cross sections. Each cross section was represented by 12 to 30 electron micrographs. Final magnification of the prints used for preparation of the montages was $9,882 \mathrm{X}$ (original magnification $3,294 X)$.

In 16 reconstructed microglial cells, participating in formation of three classical plaques, the following parameters were calculated: the volume and surface of the cell and the volume of its nucleus, cytoplasm and organelles: rough endoplasmic reticulum (RER), mitochondria and dense bodies. Measurements of the area of the cross sections of the investigated structures were made using semiautomatic image analyzer Videoplan (C. Zeiss).

Volume of the cell was calculated from area of cell cross section on serially reconstructed montages and distance of investigated sections. Volumetric density and volume of cellular organelles were calculated according to Weibel. ${ }^{14}$

\section{RESUlTS}

In the three reconstructed plaques, about $80 \%$ of the surface of the amyloid star was in contact with the cell membranes of five to six microglial cells. The size of the microglial cells varied. The average volume of microglial cells in the plaques was $597 \mu \mathrm{m}^{3}$ (SD $261 \mu \mathrm{m}^{3}$ ). The volume of the smallest reconstructed cell was $403 \mu \mathrm{m}^{3}$. The cells in which cytoplasm was filled with dense bodies were the largest.

The ratio of nucleic to cytoplasmic volume was variable. The nucleus consisted of 6.7 to $17.9 \%$ of the total volume of the cell, the average being $12.3 \%$ (SD 4.1 ). The volume of the cell nucleus varied from 52 to $101 \mu \mathrm{m}^{3}$, the average being $68 \mu \mathrm{m}^{3}$ (SD 4.1). Three-dimensional reconstruction highlighted a very rich sculptured surface of the nucleus.

The most prominent features of these cells are their polymorphism and specific polarity. Their shapes vary from ellipsoid to very irregular multiprocesses cells. However, regarding their relationship to the amyloid star, all microglial cells demonstrate a clear polarity. The polarity of cells is characterized by the specific distribution of cellular organelles and infoldings of the cellular membrane which appear to be connected with a labyrinth of channels filled with the amyloid fibers.
The cell pole nearer to the amyloid star forms a well-developed system of RER, large Golgi complex, numerous vacuoles, smooth and coated vesicles and mitochondria. Centrioles are also present in this cell. The cell pole farther from amyloid deposits is poorer in cytoplasmic organelles. In some cells, this region is filled with electron-dense storage material.

\section{Rough Endoplasmic Reticulum}

In microglial cells the volume of RER is from 15 to $31 \mu^{3}$, averaging $23 \mu^{3}$ (SD $6.2 \mu \mathrm{m}^{3}$ ). RER comprises from 2.5 to $8.7 \%$ of the total volume of the microglial cytoplasm.

RER forms channels with lengths of 1 to $3 \mu \mathrm{m}$. Locally it appears as a branching system of channels. This form is commonly observed at the "amyloid pole" of the cell close to the Golgi complex (Figures 1, 2). Continuum of RER with the smooth ER (SER) membranes was frequently observed (Figures $2,4)$. In the dilated lumen of the SER, amorphic material with medium electron density was observed. Within these distended cisterns amyloid fibers were also seen. It appears that as the cisterns enlarge, they form a system of channels filled with the amyloid fibers (Figures 2,3). There appears to be a continuum between the membranes of the channels filled with the amyloid deposits and the cell membrane.

\section{Golgi Apparatus}

The Golgi apparatus is made up of three to five complexes of cisterns and vacuoles that form an irregularly shaped ring that is usually located at the amyloid pole of the cell (Figure 4). Microglial cells are relatively rich in numerous vacuoles and vesicles found near the Golgi complex. Some of the vesicles are attached to or fused with the cisterns or channels filled with amyloid fibers (Figures 3,4).

\section{Microglial Cell Interface with Amyloid Star}

From 13 to $40 \%$ of the cell surface (average approximately $26 \%$ ) borders on amyloid deposits. In this area, the membranes of the amyloid-filled channels appear to form the cell membrane (Figures 1-5). The channels are approximately $0.5 \mu \mathrm{m}$ wide and $2 \mu \mathrm{m}$ long. On random cross sections, especially on cross sections adjacent to the periphery of the amyloid star, these channels form a complicated labyrinth, resulting from interconnections of channels, ER membranes, vacuoles and vesicles.

Fusion of vesicles, especially of coated vesicles produced by Golgi apparatus, with the walls of channels is observable. All stages of fusion are evident (Figure 4).

\section{Amyloid Star}

The periphery of the amyloid star consists of multiple channels filled with amyloid fibers in a parallel fashion. As indicated above, these channels appear to be in continuity with the endoplasmic reticulum cisterns and the cell membrane. Between the amyloid-filled channels are pockets of cytoplasm containing coated and smooth vesicles, aggregates of free ribosomes, and scattered dense bodies (Figures 5, 6). In the transient, deeper zone the pockets of trapped cytoplasm in between the amyloid deposits show evidence of degenerating cytoplasmic organelles (Figures 5,6).

In the center of the star, the amyloid fibers retain the parallel arrangement seen at the periphery of the plaque; however, in comparison to the periphery, the aggregates of the amyloid fibers are packed more densely at the center. The length and 



Figure I-Microglia cell $(M C)$ round amyloid star $(A)$. Channels filled with amyloid fibers (arrowheads). Cytoplasm rich in rough endoplasmic reticulum (rer). Clusters of dense bodies (db). $12,000 \mathrm{X}$

Figure 2 - Amyloid pole of microglia cell with mitochondria $(m)$, rough endoplasmic reticulum (er), Golgi apparatus (G), vesicles and vacuoles (v). Accumulation of granular and fibrillar material in distended, endoplasmic reticulum. Relatively regular, parallel arrangement of amyloid fibers in intracytoplasmic channels (A). 55,000X 

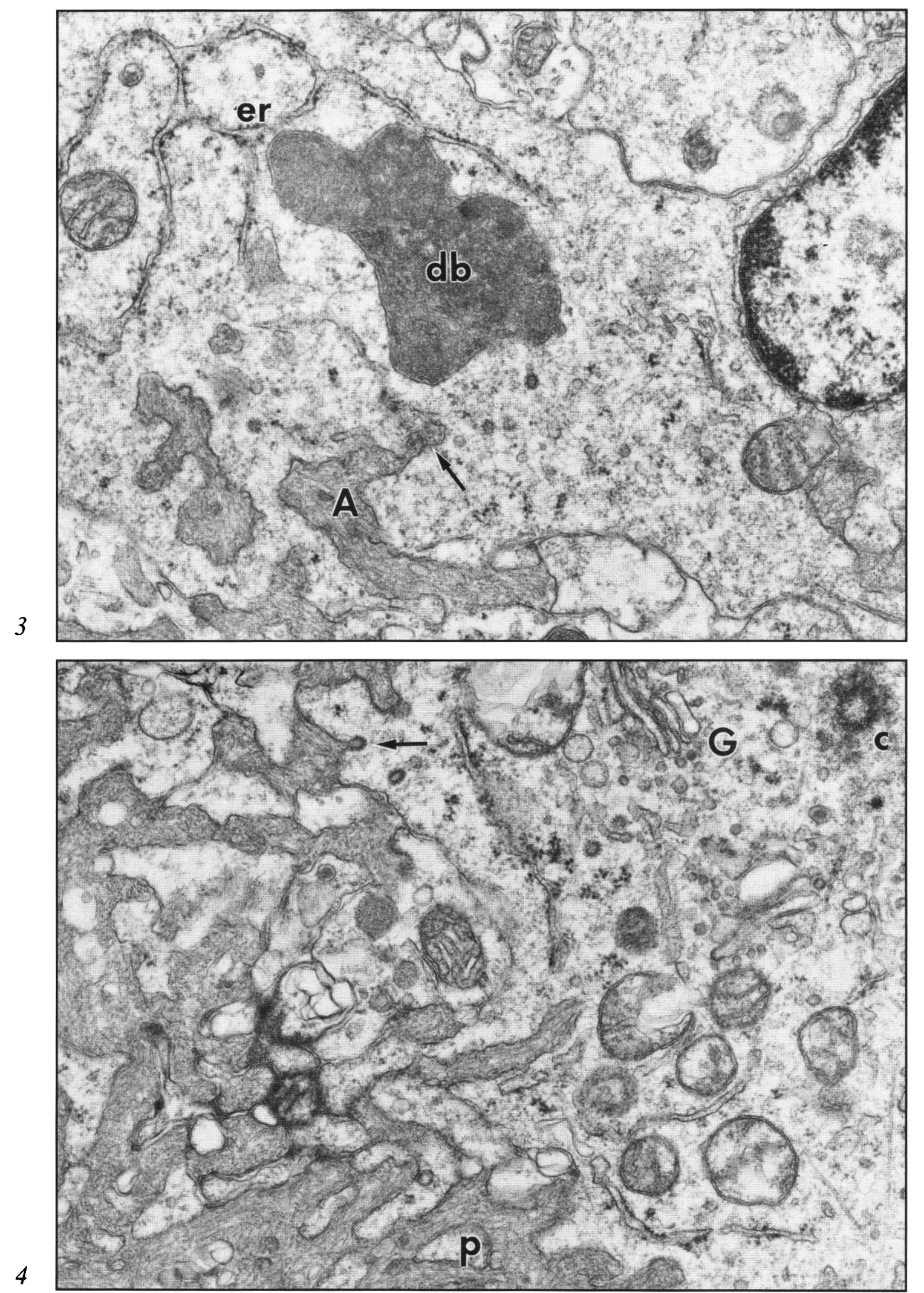

Figure 3 - Branched system of amyloid channels (A) resembles the cellular system of endoplasmic reticulum (er). Direct communication of ER and amyloid channels (arrow). Dense body (db). 33,000X

Figure 4-Labyrinth of amyloid channels interspersed with cytoplasmic pockets (p). Absence of ER in cytoplasm trapped between amyloid channels. Region of the Golgi apparatus $(G)$ rich in vacuoles and vesicles. Fusion of coated vesicles with amyloid channels walls (arrow). Centriole (c). $33.000 X$ 
width of the amyloid packages in the core of the star are smaller than those at the periphery (Figure 6). The central part of the amyloid star is more homogeneous. This region is almost completely free of dense bodies, vacuoles, vesicles and membranaceous formations. In the center of the star the bundles of amyloid fibers retain the arrangements of the amyloid fibers seen in the channels at the periphery of the plaque (Figure 6).

\section{Mitochondria}

Cross sections of the mitochondria from microglial cells were oval and their maximum diameter ranged between 0.5 and $1.5 \mu \mathrm{m}$. Sporadically, the cross sections are V-shaped or ramified. The mitochondrial cristae are located transversely to the long axis of the mitochondria. Approximately $20 \%$ of mitochondria revealed focal rarefaction of the matrix, and deformation and focal disintegration of the cristae (Figures 2-4). The volume of the mitochondria comprised from 1.4 to $3.1 \%$ of the total volume of the cytoplasm (SD 1.5\%).

\section{Dense Bodies}

The quantity of dense bodies and their shape, size and composition are variable in microglial cells of classical plaques. The total volume of the structures varied from 1.2 to $431 \mu \mathrm{m}^{3}$, that is, from 0.3 to $44 \%$ of the cytoplasmic volume of 16 reconstructed cells. On the average, those structures made up approximately $30 \%$ of the cytoplasmic volume (SD 18\%). In each plaque, there are one or two cells that are filled with osmiophilic bodies. In the other cells, dense bodies comprised only a small percentage of the total volume of cytoplasm.

Dense bodies are very heterogeneous. Most of them appeared to be composed of osmiophilic granular material (Figures 1, 3). They also contain vacuoles that appear as lipid droplets with low electron density and with diameters ranging from 0.2 to $1.5 \mu \mathrm{m}$. Such vacuoles make up approximately $9.5 \%$ of the volume of the dense bodies. The third components are osmiophilic lamellar aggregates. The same cells also contain phagosomes containing remnants of the cellular structures in different stages of disintegration, segregation and condensation.

\section{Centriole}

In reconstructed cells, the centriole is usually located in the vicinity of the nucleus, in the indentation between its lobes. Sometimes they are found near the Golgi complex (Figure 4). Centrioles contain numerous medium-length and long microtubules radiating from the active center. Usually the cellular centriole is located between the nucleus and the interface of the cells with the amyloid star.

\section{Discussion}

The serial cross sections and three-dimensional reconstruction of the classical plaque showed that five to six cells are closely associated with the amyloid star. These cells cover over $80 \%$ of the surface of the amyloid star. Ultrastructurally, they show clear polarization, with specific reorganization of the cytoplasm and the cellular membrane on the border with amyloid deposits. The first amyloid fibers appear in the distended cisterns of smooth ER. With increasing accumulation of amyloid, the altered ER forms a complex labyrinth of channels whose membranes appear to fuse with the cell membrane. Generally, from 13 to $40 \%$ of the individual cell surface is associated with the deposits of amyloid fibers.

The other pole of the cell contains the nucleus, other cytoplasmic organelles and electron-dense bodies. Between the nucleus and the amyloid-producing pole is a large Golgi complex and well developed system of RER and numerous vacuoles, as well as smooth and coated vesicles. In some cells, centrioles were found. Frequently, the smooth and coated vesicles were observed to fuse with membranes of amyloid-containing channels. Reconstruction of the amyloid star and the microglial cell pole that forms the amyloid star reveals three different zones of distribution of cytoplasmic organelles and amyloid deposits. The peripheral zone is composed of fingerlike aggregates of amyloid-filled channels. Newly formed deposits of the amyloid fibers are loosely packed. Numerous coated and smooth vesicles are present in this region, many of which attach to and fuse with the membranes of the amyloid-containing channels. Pockets of the cytoplasm that occur between channels filled with newly formed amyloid appear normal. The second zone, called the transient zone, is made up of fingerlike aggregates of amyloid and debris of degenerating cytoplasm trapped between amyloid aggregates. The peripheral and transient zones of the amyloid star are rich in nucleoside diphosphatase. ${ }^{15}$

The core of the amyloid star is made up of densely packed amyloid fibers, which usually retain their parallel arrangement. The core is usually free of dense bodies and degenerating cytoplasmic organelles that are present in the transient zone of the star. The absence of cellular debris in this area suggests that the matrix of the amyloid star contains enzymes that are able to degrade degenerating cytoplasmic organelles.

On the basis of the morphology and histochemical data ${ }^{15}$ that demonstrated nucleoside diphosphatase activity in the endoplasmic reticulum and the cisterns filled with amyloid, we concluded that these cells are the brain microglia/macrophage cells. Because the amyloid fibers are first seen in the distended cisterns of the SER system, we assumed that these cells are engaged in the formation, not the phagocytosis, of the amyloid fibers. We hypothesize that the microglia/macrophage cells synthesize and secrete the beta-peptide (they are probably both the producer and processor cells), either as an overexpressed, truncated gene product or an aberrant peptide resulting from abnormal post-translational processing.

The same configuration of cellular membranes on the border with amyloid deposits was observed in microglial cells in brains of aged dogs and in brains of mice with scrapie. $16-18$ It is also observable in other types of cells that produce amyloid deposits in experimental amyloidosis of mice: fixed reticular cells and sinus lining cells in the spleen, Kupffer cells in the liver, kidney mesangial cells and endothelial cells. ${ }^{19-23}$ According to the current concepts based on studies of systemic amyloidosis, the formation of amyloid fibers is a two-step process consisting of the production of amyloidogenic protein, which is further processed, either locally or at distant sites, to yield amyloid fibers. In most forms of amyloidosis, one type of cell produces the amyloidogenic proteins, for example, hepatocytes in secondary amyloidosis. $24-26$

As indicated above, we hypothesized that the microglia/macrophage is both the producer and the processor cell. However, Glenner and Wong suggested that the precursor pro- 

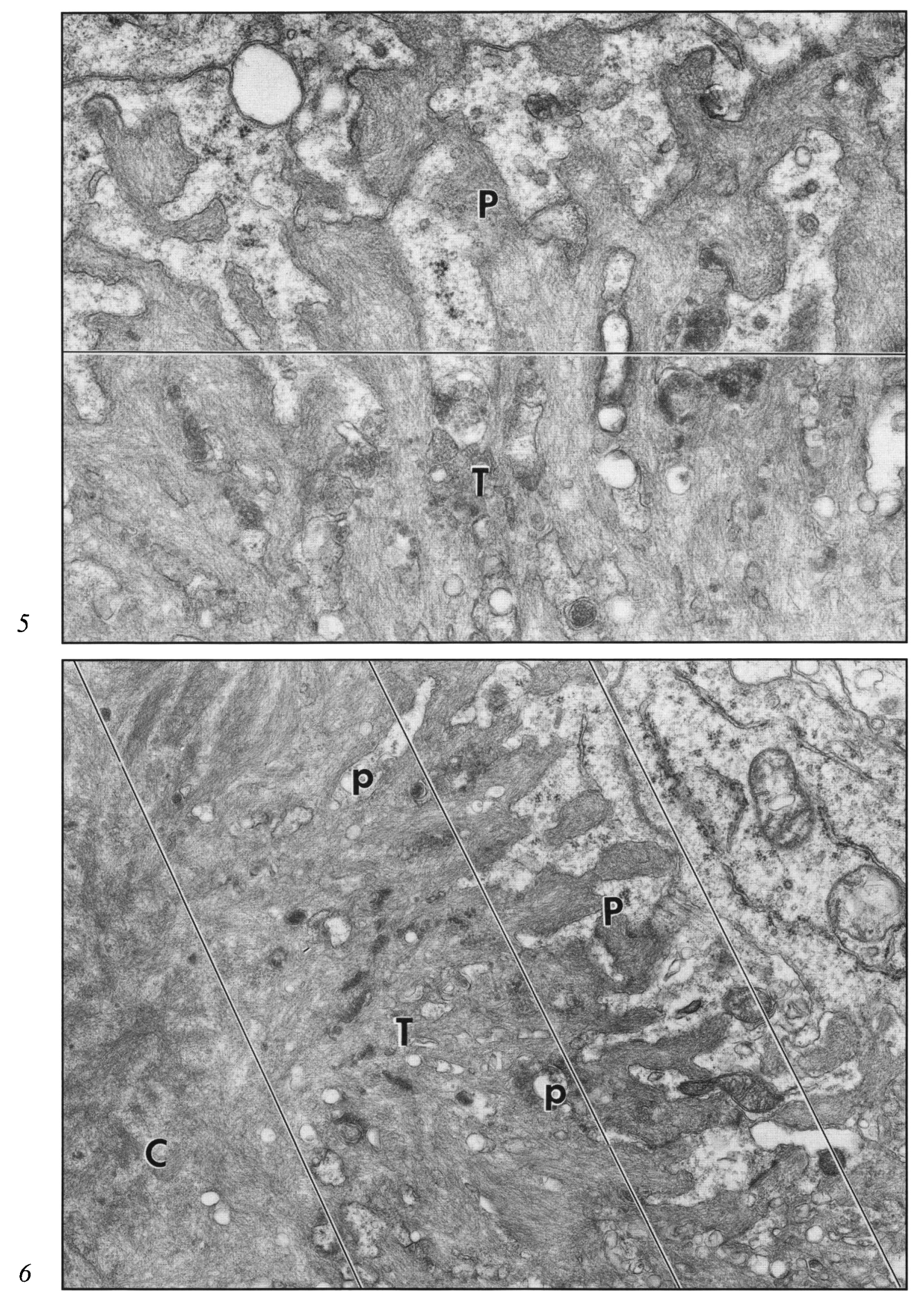

Figure 5-Periphery $(P)$ of the amyloid star formed by channels filled with amyloid fibers. Transient zone $(T)$ is a mixture of trapped fragments of cytoplasm isolated between amyloid clusters. Degeneration of trapped cytoplasmic fragments, coalescence of amyloid-filled channels. $55,000 X$

Figure 6-Peripheral $(P)$, transient $(T)$ and central $(C)$ zone of the amyloid star. Regular arrangement of newly synthesized amyloid fibers in amyloid channels in peripheral zone. Mixture of amyloid clusters with products of disintegration of cytoplasmic pockets $(p)$ trapped in transient zone. Condensation of amyloid deposits in the plaque center (C). 33,000X 
tein is derived from blood and is processed in the brain. 27,28 Other investigators suggested that the amyloid protein precursor comes from neurons ${ }^{29-34}$ or cells associated with the vessels. ${ }^{35}$

Many aspects of the process by which the 33-kd apolipoprotein $E$ (ApoE) is secreted by macrophages spread on an immune complex-coated surface ${ }^{36}$ are similar to morphological changes seen in microglial cells involved in the synthesis of amyloid fibers. In the secretion of ApoE, there is macrophage polarization with (1) redistribution of cell organelles such as Golgi apparatus, coated vesicles and secretory granules, (2) transformation of cellular membranes with formation of deep invaginations on the adherent surface, and (3) fast secretion of the ApoE. This polypeptide is found throughout the secretory pathway. It is found in lower concentrations in the endoplasmic reticulum and stacks of the Golgi complexes and in higher concentrations in the secretory granules. ApoE is also seen intracellularly in a more dilute form in large vacuoles that are contiguous with the basal cell surface. ${ }^{36-38}$

Recently while studying the metabolism of heparan sulfate proteoglycan, Iozzo ${ }^{39}$ showed a progressive movement of the newly synthesized proteoglycan from the Golgi to the cell surface, where it became closely associated with the plasma membrane. Cell-surface and extracellular proteoglycans are internalized by the cell and converted into a series of progressively smaller pieces by proteolysis of the core protein and endoglycosidic cleavage of the heparan sulfate side chains. The final degradation products are then released from the cell. The deglycosylation of the small peptide could lead to its precipitation. ${ }^{39}$ Many studies of microglial cells emphasize the enormous metamorphic capacity of microglial cells and their functional plasticity. Microglial cells may function in astrocytic differentiation and in mediation of immunological processes, ${ }^{40.41}$ or as antigenpresenting cells, thus representing effector cells. ${ }^{41}$ Involvement of the immune system in the pathogenesis of systemic amyloidosis is well documented. ${ }^{42,43}$ Recent studies by Rogers and colleagues 44 and McGeer and co-workers ${ }^{45}$ demonstrate the presence in $\mathrm{AD}$ brain of all elements of immune-competent cells. The presence of these cells in the brain is of great importance because, on proper antigenic stimulation by as yet undetermined antigen(s), these cells can initiate the same cascade of reactions that leads to amyloid formation in systemic amyloidosis, by macrophages, Kupffer cells, or hepatocytes. ${ }^{19-23}$ The fact that in AD beta peptide amyloid deposits are found only in the brain underscores the importance of organ-specific conditions needed for amyloid deposits.

\section{ACKNOWLEDGEMENTS}

The authors wish to thank Maureen Stoddard for editing the manuscript and Marjorie Agoglia and Michelle Mann for secretarial and editorial assistance. Dr. M. Kujawa was supported by Fellowship FO TWO 3849 from the Fogarty International Center, National Institutes of Health (NIH). Supported in part by NIH grants PO-1-AGO-4220-05 and PO-1-HD-22634-03.

\section{REFERENCES}

1. Del Rio-Hortega P. Microglia. In: Penfield W., ed. Cytology and Cellular Pathology of the Nervous System. New York: Hoeber $1932 ; 482-534$

2. Eager RP, Eager PR. Glial responses to degenerating cerebellar cortico-nuclear pathways in the cat. Science 1966; 153: 553-555.
3. King JS. A light and electron microscope study of perineuronal glial cells and processes in the rabbit neocortex. Anat Rec 1986; 161: $111-124$.

4. Kruger L, Maxwell DS. Electron microscopy of oligodendrocytes in normal rat cerebrum. Am J Anat 1966; 118: 411-436.

5. Cammermeyer J. Morphologic distinctions between oligodendrocytes and microglia cells in the rabbit cerebral cortex. Am J Anat 1966; 118: 227-248.

6. Mori S, Leblond CP. Identification of microglia in light and electron microscopy. J Comp Neurol 1969; 135: 57-80.

7. Murabe Y, Sano Y. Morphological studies of neuroglia. l. Electron microscopic identification of silver impregnated glia cells. Cell Tissue Res 1981; 216: 557-568.

8. Vaughn JE, Peters A. A third neuroglia cell type. An electron microscopic study. J Comp Neurol 1968; 133: 269-288.

9. Miles JM, Chou SM. A new immunoperoxidase marker for microglia in paraffin section. J Neuropathol Exp Neurol 1988; 47: 579-587.

10. Murabe Y, Sano Y. Morphological studies of neuroglia. Postnatal development of microglia cells. Cell Tissue Res 1982; 225: 469485.

11. Brierley JB, Brown $\mathrm{W}$. The origin of lipid phagocytes in the central nervous system. I. The intrinsic microglia. J Comp Neurol 1982; 211: 397-406.

12. Terry RD, Wisniewski HM. The ultrastructure of the neurofibrillary tangle and the senile plaque. $I n$ : Wolstenholme GEW, O'Connor M, eds. Ciba Foundation Symposium on Alzheimer's Disease and Related Conditions. London: Churchill 1970; 145-168.

13. Wisniewski HM, Terry RD. Reexamination of the pathogenesis of the senile plaques. In: Zimmerman HM, ed. Progr Neuropath 1973; 2: 1-26.

14. Weibel ER. Sterological methods. Vol. 1. Practical Methods for Biological Morphometry. London: Academic Press 1979.

15. Vorbrodt AW, Wisniewski HM. Plasmalemma-bound nucleosidediphosphatase as a cytochemical marker of central nervous system (CNS) mesodermal cells. J Histochem Cytochem 1982; 30: 418-424.

16. Vorbrodt $\mathrm{AW}$, Dobrogowska $\mathrm{DH}, \mathrm{Kim} \mathrm{KS}$, et al. Ultrastructural studies of glycoconjugates in brain micro-blood vessels and amyloid plaques of scrapie-infected mice. Acta Neuropathol (Berl) 1988; 75: 277-287

17. Wisniewski HM, Moretz RC, Lossinsky AS. Evidence for induction of localized amyloid deposits and neuritic plaques by an infectious agent. Ann Neurol 1981; 10: 517-522.

18. Wisniewski HM, Vorbrodt AW, Moretz RC, et al. Pathogenesis of neuritic (senile) and amyloid plaque formation. $I n$ : Hoyer $S$, ed. The Aging Brain - Physiological and Pathophysiological Aspects, Exp Brain Res. (Suppl 5). Heidelberg: Springer 1982; 3-9.

19. Bari WA, Pettengill OS, Sorenson GD. Electron microscopy and electron microscopic autoradiography of splenic cell cultures from mice with amyloidosis. Lab Invest 1969; 20: 234-242.

20. Cohen AS. The constitution and genesis of amyloid. Int Rev Exp Pathol 1965; 4: 159-243.

21. Cohen AS, Gross E, Shirahama T. The light and electron microscopic autoradiographic demonstration of local amyloid formation in spleen explants. Am J Pathol 1965; 47: 1079-1111.

22. Mandema E, Ruinen L, Scholten JH, et al. Amyloidosis. Amsterdam Excerpta Medica Foundation 1968; 463.

23. Shirahama R, Cohen AS. An analysis of the close relationship of lysosomes to early deposits of amyloid. Am J Pathol 1973; 73: 97-114.

24. Wegelius $O$. The place of amyloidosis in experimental and clinical medicine. In: Wegelius $\mathrm{O}$, Pasternack A, eds. Amyloidosis. London: Academic Press 1976; 1-13.

25. Glenner GG. The bases of the staining of amyloid fibers: their physico-chemical nature and the mechanism of their dye-substrate interaction. Progr Histochem Cytochem 1981; 13: 1-37.

26. Wisniewski HM, Wrzolek M. Pathogenesis of amyloid formation in Alzheimer's disease. Down's syndrome and scrapie. $I n$ : Novel Infectious Agents and the Central Nervous System (Ciba Foundation Symposium 135). Chichester: John Wiley \& Sons 1988; 224-238. 
27. Glenner GG, Wong CW. Alzheimer's disease: initial report of the purification and characterization of a novel cerebrovascular amyloid protein. Biochem Biophys Res Commun 1984; 120: 885-890.

28. Glenner GG, Wong CW. Amyloid research as a paradigm for Alzheimer's disease. In: Glenner GG, Osserman EF, Benditt EP, et al, eds. Amyloidosis. New York: Plenum Press 1986; 693-701.

29. Allsop D, Landon M, Kidd M, et al. Monoclonal antibodies raised against a subsequence of senile plaque core protein react with plaque cores, plaque periphery and cerebrovascular amyloid in Alzheimer's disease. Neurosci Lett 1986; 68: 252-256.

30. Bahmanyar S, Higgins GA, Goldgaber D, et al. Localization of amyloid beta protein messenger RNA in brains from patients with Alzheimer's disease. Science 1987; 237: 77-80.

31. Masters CL, Multhaup G, Simms G, et al. Neuronal origin of a cerebral amyloid: neurofibrillary tangles of Alzheimer's disease contain the same protein as the amyloid of plaque cores and blood vessels. EMBO J 1985; 4: 2747-2763.

32. Glenner GG. Congophilic microangiopathy in the pathogenesis of Alzheimer's syndrome (presenile dementia). Med Hypotheses 1979; 5: 1231-1236.

33. Powers JM, Spicer SS. Histochemical similarity of senile plaque amyloid to apudamyloid. Virchows Arch [Pathol Anat] (A) 1977; 376: 213-222.

34. Powers JM. Senile cerebral amyloid - evidence for a neuronal origin of the fibril protein. In: Glenner GG, Osserman EF, Benditt EP, et al, eds. Amyloidosis. New York: Plenum Press 1986; 743 749.

35. Miyakawa T, Sumiyoshi S, Murayama E, et al. Ultrastructure of capillary plaque-like degeneration in senile dementia. Mechanism of amyloid production. Acta Neuropathol (Berl) 1974; 29: 229-236.

36. Werb Z, Takemura R, Stenberg PE, et al. Directed exocytosis of secretory granules containing apolipoprotein $\mathrm{E}$ to the adherent surface and basal vacuoles of macrophages spreading on immobile immune complexes. Am J Pathol 1989; 134: 661-670.

37. Werb Z, Chin JR, Takemura R, et al. Control of apolipoptoyrin E secretion by macrophages, mononuclear phagocytes: characteristics, physiology and function. In: van Furth R., ed. Mononuclear Phagocyteso Doradrecht: Martinus Nijhoff 1985; 269-277.

38. Bainton DF, Takemura R, Stenberg PE, et al. Rapid fragmentation and reorganization of Golgi membranes during frustrated phagocytosis of immobile immune complexes by macrophages. Am J Pathol 1989; 134: 15-26.

39. Iozzo RV. Turnover of heparan sulfate proteoglycan in human colon carcinoma cells. A quantitative biochemical and autoradiographic study. J Biol Chem 1987; 262: 1888-1900.

40. Giulian D. Ameboid microglia as effectors of inflammation in the central nervous system. J Neurosci Res 1987; 18: 155-171.

41. Streit WJ, Graber MB, Kreutzberg GW. Functional plasticity of microglia: a review. Glia 1988; 1: 301-307.

42. Cathcart ES, Mullarkey M, Cohen AS. Cellular immunity in casein-induced amyloidosis. Immunology 1971; 20: 1001-1008.

43. Durie BGM, Persky B, Soehnlen B, et al. Amyloid production in human myeloma stem-cell culture, with morphologic evidence of amyloid secretion by associated macrophages. New Engl J Med 1982; 307: 1689-1692.

44. Rogers J, Luber-Narod J, Mufson EJ, et al. Presence of immune system markers in human brain and their potential role as a primary pathogenetic mechanism in Alzheimer's disease. $I n$ : Finch CE, Davies P, eds. The Molecular Biology of Alzheimer's Disease. Current Communications in Molecular Biology. Cold Spring Harbor Laboratory 1988; 51-56.

45. McGeer PL, Itagaki $\mathrm{S}$, Akiyama $\mathrm{H}$, et al. Immune system response in Alzheimer's disease. In: Finch CE, Davies P, eds. The Molecular Biology of Alzheimer's Disease. Current Communications in Molecular Biology. Cold Spring Harbor Laboratory $1988 ; 47-50$. 